\title{
Karakterisasi Lima Galur Cabai Hias dalam Rangka Pendaftaran Varietas Hasil Pemuliaan
}

\section{Characterization of Five Lines of Ornamental Chili Pepper Plant for Registration of New Variety}

\author{
Sulassih $^{1}$, Muhamad Syukur ${ }^{1,2^{*}}$, Sobir ${ }^{1,2}$, Awang Maharijaya ${ }^{1,2}$, Abdul Hakim ${ }^{2}$, Ratih $^{2}$ \\ ${ }^{1}$ Pusat Kajian Hortikultura Tropika, LPPM IPB, Jl. Raya Pajajaran Baranangsiang, Bogor, Indonesia \\ ${ }^{2}$ Departemen Agronomi dan Hortikultura, Fakultas Pertanian IPB, Jl. Meranti Darmaga, Bogor, Indonesia \\ *Penulis untuk korespondensi. email: muhsyukur@ipb.ac.id
}

Diterima 12 November 2016/Disetujui 9 Januari 2017

\begin{abstract}

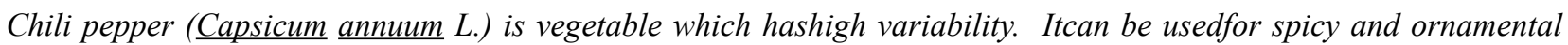
plant. The aim of this study isto obtain both quantitative and qualitative dataof five lines ornamental chili pepper for plant protection program and new variety. Clustering analyzed using NTSYS 2.0 software and principle component analyzed using MINITAB 16.2.1. Clustering analysis showed five groups of chili pepper base on 75\% coefficient similarity with 0.95 goodnest of fit. The groups are consist of group A for Ayesha, group B for Syakira and Namira, group C forSeroja, group $D$ forJelita and group E for Lembayung. Principle component analysis showed cumulative value at 0.778 on PC3. The characters which made the groups are purple stem color (0.233), greenupper leaves color (-0.232), purplelower leaves color (0.232), redmature fruit color (0.266), short fruit size (0.266), and medium seed size (-0.338). Ayesa have triangular fruit shape and obtuse shape apex.Jelita recorded sparse habitus, small fruit, shortened internode, and short plant. Namira have shortened internode but Syakira showed intermediate habitus and dont have shortened internode. Lembayung showed purple on upper and lower leaves, stem, stigma, corolla, immature fruit and orange on fruit mature. Ayesha, Namira, Seroja, Jelita and Lembayung potential for plant variety registration as new variety.
\end{abstract}

Keywords: Ayesha, Jelita, Lembayung, Namira, Seroja, Syakira

\section{ABSTRAK}

Cabai (Capsicum annuum L.) merupakan tanaman sayuran memiliki keragaman yang luas. Cabai dapat dijadikan sebagai tanaman hias selain untuk bahan konsumsi. Kegiatan ini bertujuan untuk mendeskripsikan karakter kuantitatif dan kualitatif lima galur cabai hias hasil pemuliaan tanaman. Karakterisasi dilakukan menggunakan metode pengelompokan terhadap varietas pembanding yang sudah mendapatkan tanda pendaftararan varietas. Pengelompokan menggunakan software NTSYS versi 2.0dan analisis komponen utama menggunakan software MINITAB versi 16.2.1. Pengelompokan keenam galur pada koefisien kemiripan 75\% menunjukkan lima kelompok dengan nilai goodnest of fit sebesar 0.95 . Kelompok A adalah galur Ayesha, kelompok B terdiri dari Syakira dan Namira, kelompok Cadalah Seroja sekaligus sebagai pembanding, kelompok $D$ adalah Jelita, dan kelompok E adalah Lembayung. Analisis komponen utama diperoleh pada komponen ke-3 (PC3) dengan nilai kumulatif sebesar 0.778. Karakter yang mempengaruhi pengelompokan antara lain warna batang ungu (0.233), warna permukaan atas daunhijau (-0.232), warna permukaan bawahdaun ungu (0.232), warna buah masak merah (0.266), buah pendek (0.266), dan ukuran biji sedang (-0.338). Ayesa memiliki karakter bentuk buah segitiga (triangular) dan ujung buah tumpul. Jelita memiliki karakter tajuk menyebar, buah kecil, terdapat pemendekan buku, dan tanaman pendek. Namira memiliki karakter pemendekan buku, sedangkan Syakira memiliki tajuk intermediate dan tidak ada pemendekan buku. Lembayung memiliki karakter daun, warna batang, dan warna mahkota berwarna ungu serta buah masak berwarna orange tua. Galur Ayesha, Namira, Seroja, Jelita, dan Lembayung berpotensi untuk didaftarkan sebagai varietas baru cabai hias.

Kata kunci: Ayesha, Jelita, Lembayung, Namira, Seroja, Syakira

\section{PENDAHULUAN}

Cabai (Capsicum annuum L.) memiliki keragaman dalam bentuk buah, warna buah, tipe buah, rasa, dan kandungan biokimia. Cabai berpotensiuntuk dimanfaatkan sebagai bahan pangan, nutrisi, obat-obatan, dan kosmetik (Dagnoko et al., 2013). Cabai mengandung vitamin A, C, K,
B6, kalsium, zat besi, seng, serat dan capsaicin. Capsaicin (C18H27NO3) termasuk ke dalam golongan alkaloid dan hanya ditemukan pada cabai. Capsaicin memberikan rasa pedas dan bermanfaat sebagai anti kanker serta anti oksidan (Dagnoko et al., 2013). Cabai hias bermanfaat untuk konsumsi segar, bumbu, tanaman hias dalam pot, dan tanaman untuk taman (Ari et al., 2016). Tanaman cabai 
hias berpotensi untuk dikomersialisasikan dengan harga yang lebih tinggi dan dapat dijadikan sebagai produk baru karenaperbanyakan benihnya mudah, berumur pendek, tahan cekaman kekeringan dan genangan, memiliki variasi warna bunga dan buah (Ari et al., 2016).

Keragaman genetik pada genus Capsicum sangat tinggi sehingga dapat dikembangkan untuk peningkatan hasil produksi, kualitas buah, kandungan nutrisi, dan ketahanan terhadap hama dan penyakit. Pengembangan cabai hias masih terbatas dan belum menjadi komoditi utama. Pengembangan cabai hias memiliki kendala untuk mendapatkan karakter seleksi untuk pertumbuhan yang cepat, tahan terhadap hama dan penyakit, serta kemampuan hidup tanaman, sehingga pengembangan cabai hias ditujukan untuk mendapatkan tanaman yang cepat pertumbuhannya, tanaman berukuran pendek dan memiliki nilai estetika (Rego et al., 2012).

Pusat Kajian Hortikultura Tropika (PKHT) LPPM IPB danDepartemen Agronomi dan Hortikultura (AGH) Fakultas Pertanian IPB memiliki galur cabai hias hasil persilangan yang berpotensi untuk dikembangkan sebagai calon varietas baru. Ideotipe yang diharapkan dari hasil persilangan adalah untuk mendapatkan (1) ukuran tanaman dwarf, (2) buah membulat, (3) buah memanjang, (4) ada pemendekan ruas, (5) buah lebat, (6) buah banyak warna dalam satu tanaman, dan (7) buah berwarna ungu. Varietas yang sudah mendapatkan sertifikat tanda daftar varietas cabai hias adalah varietas Seroja dan Ungara. Deskripsi lima galur cabai hias melalui analisis pengelompokan (clustering) diharapkan dapat membedakan lima galur cabai hias baru hasil pemuliaan dengan varietas pembanding yaitu Seroja. Galur-galur koleksi PKHT LPPM IPB danDepartemen AGH Fakultas Pertanian IPB diharapkan dapat dilanjutkan pada tahap pendaftaran varietas sesuai dengan Peraturan Menteri Pertanian Nomor : 01/Pert/SR.120/2/2006 tentang syarat penamaan dan tata cara pendaftaran varietas tanaman bagi varietas hasil pemuliaan.

\section{METODOLOGI}

Tanaman yang digunakan adalah lima galur generasi ke6 hasil persilangan (1) IPB C318 (selfing Explosive Embeer) dengan IPB C092 (selfing dari Seroja) dan (2) IPB C318 (selfing Explosive Embeer) dengan IPB C320 (selfing dari Numex Twilight). Metode pemuliaan yang digunakan adalah seleksi pedigree yang dilaksanakan di Desa Sinarsari dan kebun percobaan Leuwikopo, Darmaga, Bogor, Jawa Barat. Pengamatan di lapangan dilakukan sejak Januari 2013 - Mei 2016. Pengamatan pascapanen dilakukan di Laboratorium Pemuliaan Departemen AGH Fakultas Pertanian IPB serta laboratorium PKHT IPB Baranangsiang Bogor. Karakter Pengamatan karakter kualitatif mengacu pada Naktuinbouw (2010), IPGRI (1995) danPanduan Pengujian Individual (PPI) untuk pedoman pelaksanaan pengujian Kebaruan, Keunikan, Keseragaman dan Kestabilan (BUSS) spesies Cabai ( PPVT, 2006) seperti pada Tabel 1.

Tabel 1. Karakter pengamatan morfologi pada lima galur cabai hias

\begin{tabular}{|c|c|c|}
\hline No & Karakter & Panduan \\
\hline 1 & $\begin{array}{l}\text { Tinggi tanaman (sangat pendek }<25 \mathrm{~cm} \text {, pendek } 25-45 \mathrm{~cm} \text {, sedang } 46-65 \mathrm{~cm} \text {, } \\
\text { tinggi } 66-85 \mathrm{~cm} \text {, sangat tinggi }>85 \mathrm{~cm} \text { ) }\end{array}$ & IPGRI \\
\hline 2 & Habitus tanaman (tegak, intermediate, menyebar) & PPI, IPGRI \\
\hline 3 & Pemendekan buku (ada, tidak ada) & Naktuinbouw, PPI \\
\hline 4 & Warna batang (ungu, hijau strip ungu, hijau, hijau tua) & IPGRI \\
\hline 5 & Ukuran panjang helai daun (pendek $<3.5$, sedang $3.5-5.2$, panjang $>5.2$ ) & Naktuinbouw, PPI modifikasi \\
\hline 6 & Warna permukaan atas daun (ungu, hijau, hijau bercak ungu) & IPGRI,PPI \\
\hline 7 & Warna permukaan bawah daun (ungu, hijau) & IPGRI, PPI \\
\hline 8 & Warna kepala putik (kuning, ungu) & Observasi \\
\hline 9 & Warna mahkota bunga (ungu, putih) & IPGRI \\
\hline 10 & Warna buah muda (putih kehijauan, kuning, hijau, ungu) & Naktuinbouw \\
\hline 11 & Warna buah tua (merah, merah tua, orange) & Naktuinbouw \\
\hline 12 & Bentuk pangkal buah (tumpul/obtuse, rompang/truncate) & PPI \\
\hline 13 & Bentuk ujung buah (runcing/acute, tumpul/obtuse) & PPI \\
\hline 14 & $\begin{array}{l}\text { Panjang buah (sangat pendek }<2.3 \mathrm{~cm} \text {, pendek } 2.3-2.7 \mathrm{~cm} \text {, sedang } 2.7-4.3 \mathrm{~cm} \text {, } \\
\text { panjang }>4.3 \mathrm{~cm} \text { ) }\end{array}$ & $\begin{array}{l}\text { Naktuinbouw modifikasi, IPGRI } \\
\text { modifikasi }\end{array}$ \\
\hline 15 & Bobot buah (kecil $<0.5 \mathrm{~g}$, sedang $0.5-2 \mathrm{~g}$,besar $>2 \mathrm{~g}$ ) & IPGRI modifikasi \\
\hline 16 & Bentuk buah (segitiga/triangular, segitiga menyempit/narrowlytriangular) & Naktuinbouw, PPI \\
\hline 17 & Bentuk biji (pipih, cembung dibagian tengah) & Observasi \\
\hline 18 & $\begin{array}{l}\text { Ukuran biji (kecil bobot } 1000 \text { butir }<2.57 \mathrm{~g} \text {, sedang bobot } 1000 \text { butir } 2.57 \text { - } \\
3.70 \mathrm{~g} \text {, besar bobot } 1000 \text { butir }>3.70 \mathrm{~g}\end{array}$ & IPGRI modifikasi \\
\hline
\end{tabular}


Data hasil pengamatan morfologi dianalisis dengan menggunakan program NTSYS (Numerical Taxonomy and Multivariate Analysis) versi 2.0 (Rohlf, 1998). Hasil pengamatan morfologi diberi nilai skor 0 apabila individu tidak memiliki karakter morfologi yang diamati dan diberi nilai skor 1 apabila individu memiliki karakter sesuai pengamatan. Koefisien kemiripan berdasarkan penanda morfologi dianalisis denganmetode Simple Matching Coeficient (SM) melalui SIMQUAL (Similarity for Qualitative Data). Tingkat keselarasan pengelompokan ditentukan oleh nilai goodness of fit yaitu kesesuaian antara nilai koefisien kemiripan (SM) dengan kriteria sangat sesuai $(r \geq 0.9)$, sesuai $(0.8 \leq r<0.9)$, tidak sesuai $(0.7 \leq r<0.8)$ dan sangat tidak sesuai $(\mathrm{r}<0.7)$. Pengelompokan (clustering) dianalisis menggunakan SAHN (Sequential Agglomerative Hierarchical and Nested)-UPGMA (Unweighted pairgroup method arithmatic average). Analisis komponen utama dianalisis pada tahapan multivariate menggunakan program MINITAB versi 16.2.1. Hasil analisis berupa plot dua dimensi dan karakter pendukung pengelompokan.

\section{HASIL DAN PEMBAHASAN}

Genus Capsicum memiliki keragaman baik di dalam species maupun antar species pada tipe buah, warna buah, rasa, dan kandungan biokimia. Species Capsicum annuum terbagi menjadi 5 sub species yaitu $C$. annuum var. abbreviatum, C. annuum var. annuum, C. annuum var. accuminatum, C.annuum var.grossum, dan C.annuum var. glabriusculum (Zhigila et al., 2014). Galur cabai hias Ayesha, Syakira, Namira, Jelita, dan Lembayung termasuk C. annuum var. annuum. Pengembangan pemuliaan tanaman cabai hias ditujukan untuk karakter tanaman yang pendek, habitus intermediate, 3-5 kali panen, cepat berbunga, warna buah, ukuran buah dan bentuk buah (Silva et al., 2015). Galur cabai hias koleksi PKHT LPPM IPB berpotensi untuk dikembangkan sebagai varietas baruuntuk mendapatkan ukuran tanaman $d$ warf, buah membulat, buah memanjang, ada pemendekan ruas, buah lebat, buah banyak warna dalam satu tanaman, dan buah berwarna ungu (Gambar 1).

Karakterisasi dilakukan menggunakan metode pengelompokan terhadap varietas pembanding yaitu Seroja yang sudah mendapatkan tanda pendaftararan varietas. Hasil pengelompokan dari enam galur pada koefisien kemiripan $75 \%$ diperoleh lima kelompok dengan nilai goodnest of fit sebesar 0.95003. Kelompok yang terbentuk yaitu kelompok A untuk galur Ayesha, kelompok B terdiri dari Syakira dan Namira, kelompok C untuk Seroja sekaligus sebagai pembanding, Kelompok D untuk Jelita dan kelompok E untuk Lembayung (Gambar 2).

Galur Syakira dan Namira tampak memiliki koefisien kemiripan yang tinggi yaitu 0.89 (Tabel 2) disebabkan oleh kemiripan karakter bentuk buah, bentuk daun, dan warna daun. Karakter pembeda diantara keduanya adalah Namira memiliki karakter pemendekan buku, sedangkan Syakira tidak memiliki pemendekan buku. Kedua galur tersebut memiliki induk yang sama yaitu tetua betina IPB C318 (selfing Explosive Embeer) dan tetua jantan galur IPB C092 (selfing dari Seroja), sehingga kemiripan karakter merupakan perpaduan dari kedua tetua (Tabel 3).

Jelita, Syakira, Namira, dan Lembayung merupakan keturunan generasi ke-6 hasil persilangan IPB C318 (selfing Explosive Embeer) dengan IPB C092 (selfing dari Seroja). Metode persilangan ynag digunakan adalah pedigree. IPB C318 (selfing Explosive Embeer) merupakan donor warna buah ungu dan kelebatan buah sebagai tetua betina dan IPB C092 (selfing dari Seroja) sebagai tetua jantan donor buah berwarna kuning dan ukuran pendek (dwarf). Galur Ayesha merupakan keturunan ke-6 hasil persilangan IPB C318 (selfing Explosive Embeer) sebagai tetua betina merupakan donor warna buah ungu dan kelebatan buah dengan tetua jantan IPB C320 (selfing dari Numex Twilight) merupakan donor buah membulat dan ukuran pendek (dwarf) melalui metode persilangan pedigree. NuMex Twilight tergolong tanaman yang tahan salinitas tinggi pada konsentrasi EC $8.1 \mathrm{dSm}-1$ ( $\mathrm{NaCl}$ dan $\mathrm{CaCl} 2$ dengan rasio 2:1 molar) tanpa adanya kerusakan pada daun pucuk, tidak megalami nekrosis dan tidak terjadi perubahan warna daun (Niu, G., et al., 2012). Ideotipe yang diharapkan dari hasil persilangan adalah untuk mendapatkan ukuran tanaman dwarf, buah membulat, jumlah buah lebat dan banyak warna dalam satu tanaman (Tabel 3).

Analisis komponen utama diperoleh 5 kelompok, yaitu kelompok A terdiri dari galur Ayesha, kelompok B terdiri dari Syakira dan Namira, kelompok C yaitu Seroja sekaligus sebagai pembanding, Kelompok D yaitu Jelita dan kelompok E yaitu Lembayung (Gambar 3).

Karakter yang menentukan terbentuknya pengelompokan dapat dianalisis pada nilai Analisis Komponen Utama (AKU)/Principal Component Analysis. AKU digunakan untuk: (1) identifikasi peubah baru yang mendasari data peubah ganda; (2) mengurangi banyaknya dimensi peubah yang banyak dan berkorelasi menjadi peubah baru yang tidak berkorelasi dengan mempertahankan keragaman pada himpunan data; dan (3) menghilangkan peubah asal yang mempunyai sumbangan informasi yang relatif kecil. Banyaknya komponen utama yang dipilih yaitu apabila persentase keragaman kumulatif minimum 70\% (Supranto, 2004). Hasil analisis komponen utama pada morfologi secara kualitatif bagi limagalur cabai hias, dapat dijelaskan oleh tiga komponen utama yang mencakup hanya $77 \%$ data dari total keseluruhan data (Tabel 4).

Karakter morfologi dan agronomi bermanfaat untuk mengevaluasi dan seleksi (Occhiuto, et al., 2014). Jumlah karakter penentu pembentuk pengelompokan terpilih adalah selaras dengan nilai akar ciri yaitu tiga karakter pada komponen utama/PC1, 2 karakter pada PC3, dan 2 karakter pada PC3 (Tabel 5). Kelima genotipe berpotensi menjadi calon varietas baru karena memiliki karakter yang berbeda dengan pembandingnya yaitu Seroja. Galur Lembayung memiliki karakter yang unik dari galur lainnya yaitu memiliki karakter warna ungu pada bagian permukaan atas dan bawah daun, mahkota, kepala putik, dan buah muda (Tabel 6.). Karakter-karakter tersebut sesuai dengan hasil analisis komponen utama pada Tabel 5 yang menjadikan karakter warna daun ungu pada bagian permukaan atas dan bawah sebagai karakter penciri dan pembentuk pengelompokan. 


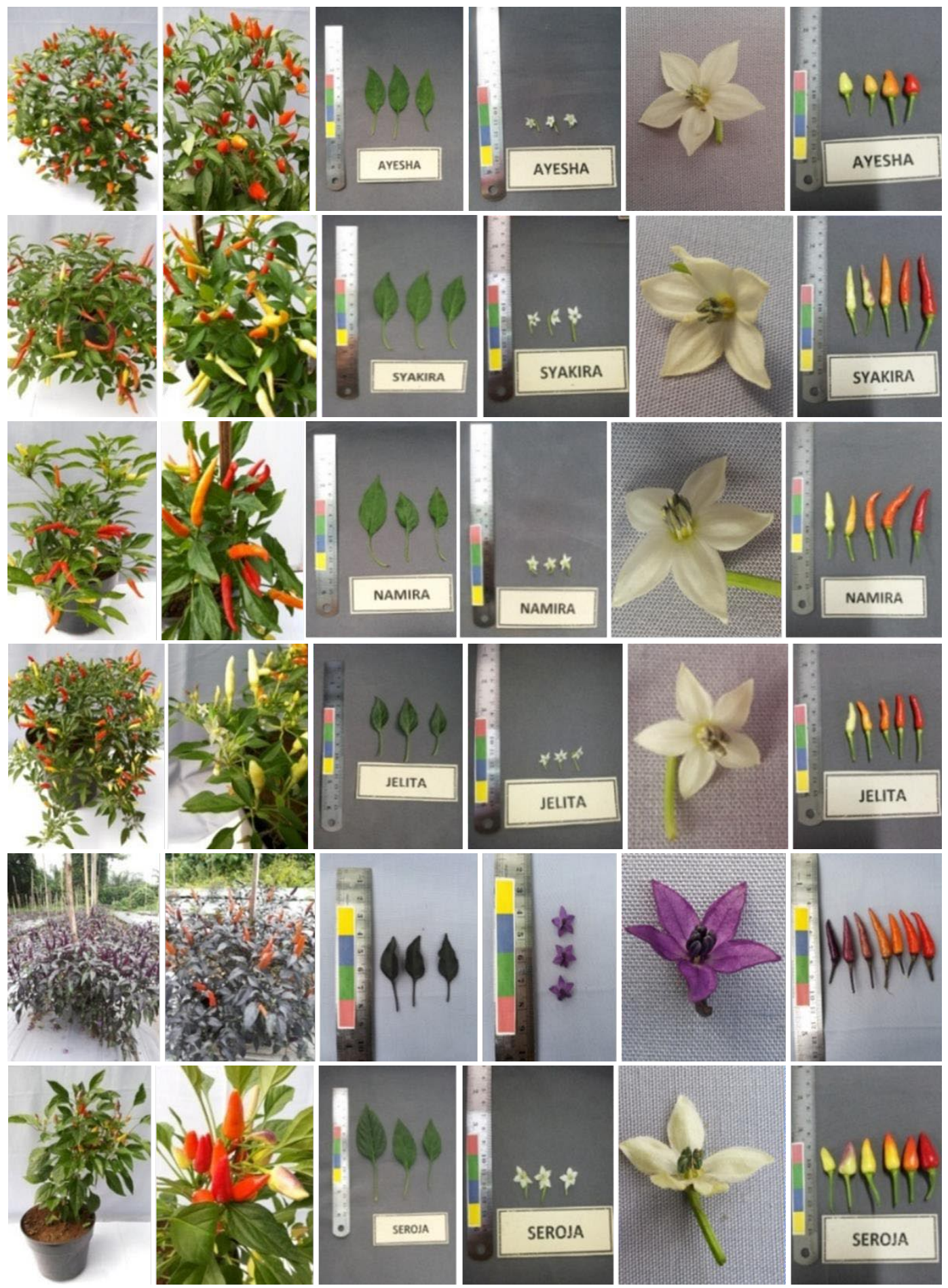

Gambar 1. Keragaan lima galur cabai hias dengan tetua jantan (Seroja) sebagai pembanding

Genus Capsicum memiliki keragaman baik di dalam species maupun antar species pada tipe buah, warna buah, rasa dan kandungan biokimia. Keragaman dapat terbentuk karena viabilitas serbuk sari $C$. annuum var. annuum sangat tinggi mencapai 90.8\% (Eduardo et al., 2011). Keragaman pada varietas cabai terdapat pada bentuk dan ukuran buah (Zhigila et al., 2014). Saat ini Genus Capsicum terdiri dari lima species hasil domestikasi dan 26 species tipe liar (Zhigila et al., 2014) yaitu C. annuum, C. baccatum, C. chinense, $C$. frutescens, dan C. pubescens (Syukur et al., 2015). Menurut Zhigila et al. (2014) species $C$. annuum terbagi menjadi 5 sub species yaitu $C$. annuum var. abbreviatum, $C$. annuum var. annuum, C. annuum var. accuminatum, C. annuum var. grossum, dan C.annuumvar. glabriusculum. C. annuum var. glabriusculum memiliki karakter bentuk buah membulat dan memiliki empat lokus (tetralocular), jumlah biji dalam satu buah sangat banyak. C. annuum var. Abbreviatum dan C.annuum var. accuminatum berkarakter cordate pada 


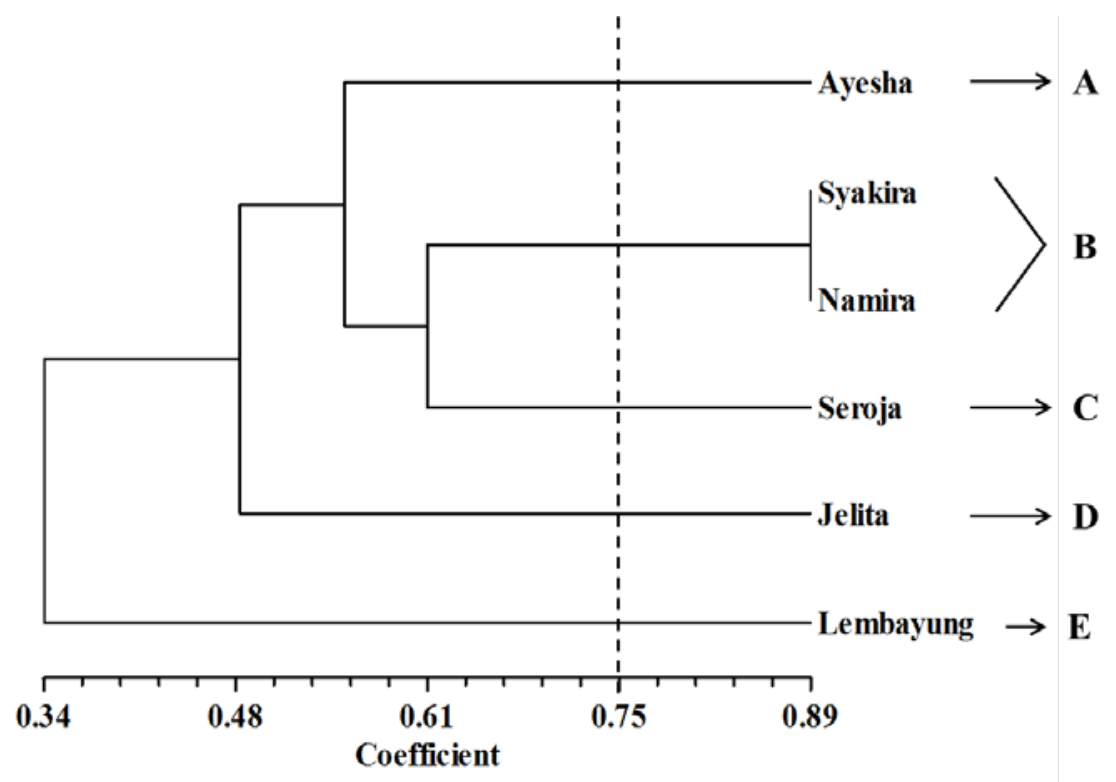

Gambar 2. Pengelompokan lima galur cabai hias

Tabel 2. Koefisien kemiripan pada 5 galur cabai hias terhadap pembandingnya

\begin{tabular}{lcccccc}
\hline & Ayesha & Jelita & Syakira & Namira & Lembayung & Seroja \\
\hline Ayesha & 1 & & & & & \\
Jelita & 0.457 & 1 & & & & \\
Syakira & 0.571 & 0.5 & 1 & & & \\
Namira & 0.571 & 0.556 & 0.889 & 1 & 1 & \\
Lembayung & 0.286 & 0.278 & 0.444 & 0.389 & 0.308 & 1 \\
Seroja & 0.526 & 0.410 & 0.615 & 0.615 & & \\
\hline
\end{tabular}

Tabel 3. Asal usul 5 galur cabai hias Ayesha, Jelita, Syakira, Namira dan Lembayung

\begin{tabular}{|c|c|c|c|c|}
\hline Galur & Tetua betina & Tetua jantan & $\begin{array}{c}\text { Metode } \\
\text { Pemuliaan }\end{array}$ & Ideotipe \\
\hline Ayesha & $\begin{array}{l}\text { IPB C318 (selfing } \\
\text { Explosive Embeer) }\end{array}$ & $\begin{array}{l}\text { IPB C320 (selfing } \\
\text { dari Numex } \\
\text { Twilight }\end{array}$ & Pedigree & $\begin{array}{l}\text { ukuran tanaman dwarf, buah membulat, jumlah buah } \\
\text { lebat dan banyak warna dalam satu tanaman }\end{array}$ \\
\hline Jelita & $\begin{array}{l}\text { IPB C } 318 \text { (selfing } \\
\text { Explosive Embeer) }\end{array}$ & $\begin{array}{l}\text { IPB C092 (selfing } \\
\text { dari Seroja), }\end{array}$ & Pedigree & $\begin{array}{l}\text { ukuran tanaman dwarf, buah memanjang, jumlah } \\
\text { buah lebat dan banyak warna dalam satu tanaman }\end{array}$ \\
\hline Syakira & $\begin{array}{l}\text { IPB C318 (selfing } \\
\text { Explosive Embeer) }\end{array}$ & $\begin{array}{l}\text { IPB C092 (selfing } \\
\text { dari Seroja), }\end{array}$ & Pedigree & $\begin{array}{l}\text { ukuran tanaman dwarf, buah memanjang, jumlah } \\
\text { buah lebat dan banyak warna dalam satu tanaman }\end{array}$ \\
\hline Namira & $\begin{array}{l}\text { IPB C } 318 \text { (selfing } \\
\text { Explosive Embeer) }\end{array}$ & $\begin{array}{l}\text { IPB C092 (selfing } \\
\text { dari Seroja), }\end{array}$ & Pedigree & $\begin{array}{l}\text { ukuran tanaman dwarf, buah memanjang, ada } \\
\text { pemendekan ruas, jumlah buah lebat dan banyak } \\
\text { warna dalam satu tanaman }\end{array}$ \\
\hline Lembayung & $\begin{array}{l}\text { IPB C318 (selfing } \\
\text { Explosive Embeer) }\end{array}$ & $\begin{array}{l}\text { IPB C092 (selfing } \\
\text { dari Seroja), }\end{array}$ & Pedigree & $\begin{array}{l}\text { ukuran tanaman dwarf, buah memanjang, jumlah } \\
\text { buah lebat dan berwarna ungu dalam satu tanaman }\end{array}$ \\
\hline Seroja & Sumber tetua & Sumber tetua & $\begin{array}{l}\text { Seleksi } \\
\text { Massa }\end{array}$ & $\begin{array}{l}\text { galur murni dengan ukuran, bentuk dan warna buah } \\
\text { seragam, jumlah buah banyak, ada pemendekan ruas, } \\
\text { terdiri dari beberapa warna buah dalam satu tanaman, } \\
\text { orientasi buah mengarah ke atas }\end{array}$ \\
\hline
\end{tabular}




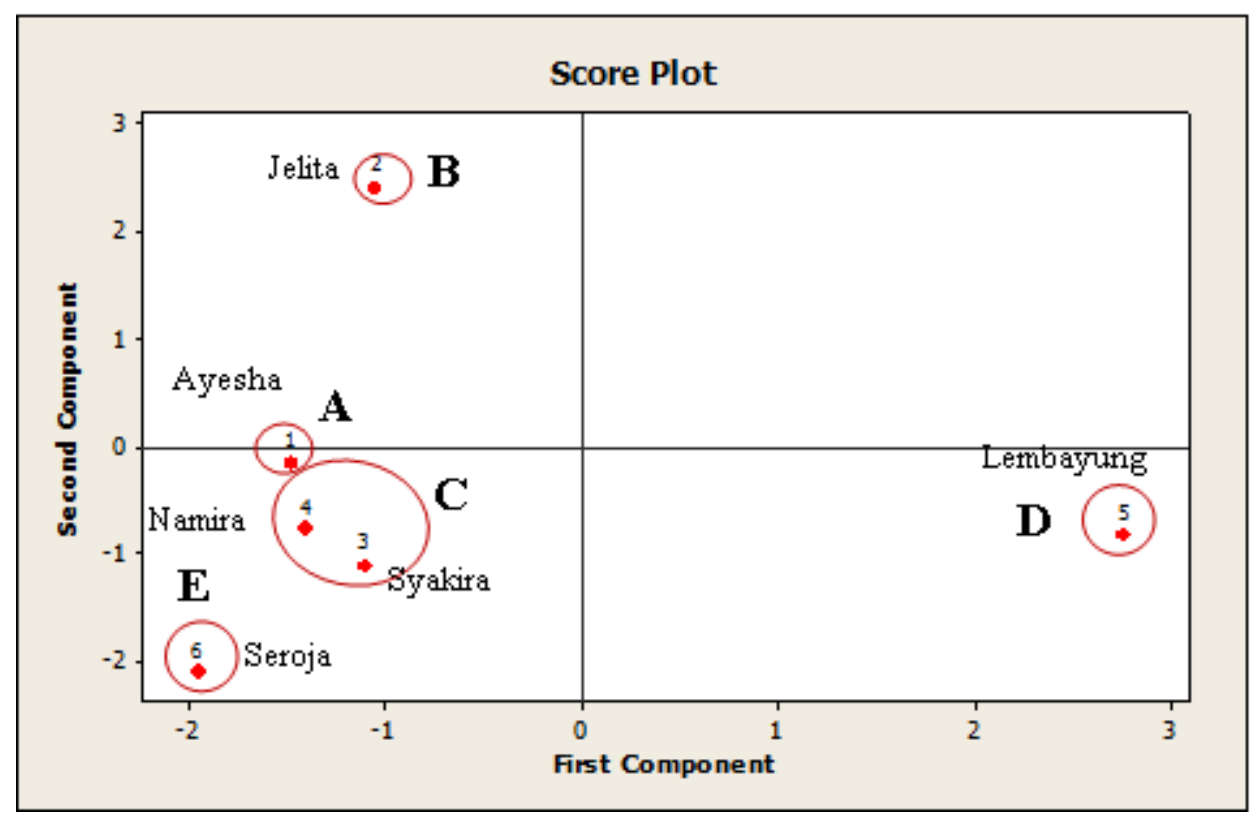

Gambar 3. Nilai analisis komponen utama pada karakter morfologi lima galur cabai hias dan pembandingnya

Tabel 4. Nilai analisis komponen utama pada karakter morfologi

\begin{tabular}{lccc}
\hline & PC1 & PC2 & PC3 \\
\hline Akar ciri & 2.983 & 2.338 & 1.886 \\
Proporsi & 0.322 & 0.252 & 0.203 \\
Akumulasi & 0.322 & 0.574 & 0.778 \\
Jumlah karakter & 3 & 2 & 2 \\
\hline
\end{tabular}

Tabel 5. Karakter morfologi pembentuk komponen utama

\begin{tabular}{lclc}
\hline Komponen utama & Jumlah karakter & Jenis karakter & Nilai \\
\hline PC1 & 3 & Warna batangungu & 0.232 \\
& & Warna daun permukaan atas hijau & -0.232 \\
& & Warna daun permukaanbawah ungu & 0.232 \\
PC2 & 2 & Warna buah masak merah (FF6600) & 0.266 \\
& & Ukuran buah pendek & 0.266 \\
PC3 & 1 & Ukuran biji sedang & -0.338 \\
\hline
\end{tabular}

bentuk buah dan memiliki tiga lokus (trilocular), sedangkan C. annuum var. annuum bentuk buah cordate, memiliki dua lokus (bilocular), dan jumlah biji dalam satu buah sangat sedikit. Berdasarkan bentuk dan ukurannya C.annuum digolongkan menjadi empat tipe yaitu cabai besar, keriting, rawit (hijau) dan paprika (Syukur et al., 2015). Cabai hias Ayesha, Syakira, Namira, Jelita, Lembayung, dan Seroja merupakan species C. annuum var. annuum.

Karakter panjang buah adalah karakter penting untuk membedakan ukuran buah kecil, sedang, dan besar antar varietas. Karakter panjang buah menurut Zhigila et al. (2014) pada lima sub species $C$. annuum dikelompokan menjadi kecil (<50 mm), sedang (51-100 mm), dan besar/ panjang $(>101 \mathrm{~mm})$, tetapi untuk deskripsi lima galur cabai hias Ayesha, Syakira, Namira, Jelita, Lembayung, dan Seroja yang termasuk ke dalam $C$. annuum var. annuum belum ada ketentuan untuk karakter panjang buah, sehingga berdasarkan pengamatan kuantitatif dapat dikelompokan sangat pendek $<(2.3 \mathrm{~cm})$, pendek $(2.3-2.7 \mathrm{~cm})$, sedang $(2.7$ $4.3 \mathrm{~cm})$, panjang $(>4.3 \mathrm{~cm})$.

Ideotipe yang diharapkan dari hasil persilangan adalah untuk mendapatkan tanaman dengan karakter ukuran tanaman $d$ warf, buah membulat, buah memanjang, ada pemendekan ruas, buah lebat, buah banyak warna dalam satu tanaman, dan buah berwarna ungu. Galur cabai hias yang dikembangkan memiliki ciri sebagai berikut: (1) 
Tabel 6. Karakter kualitatif lima galur cabai hias potensial dan pembandingnya

\begin{tabular}{|c|c|c|c|c|c|c|}
\hline & Ayesha & Jelita & Syakira & Namira & Lembayung & Seroja \\
\hline Tinggi tanaman & sedang & pendek & Sedang & sedang & Sedang & sedang \\
\hline Habitus tanaman & intermediate & menyebar & intermediate & intermediate & Intermediate & intermediate \\
\hline Pemendekan buku & tidak ada & ada & tidak ada & ada & tidak ada & ada \\
\hline Warna batang & hijau & hijau & Hijau & hijau & Ungu & hijau tua \\
\hline Ukuran panjang helai daun & sedang & pendek & Panjang & sedang & Pendek & panjang \\
\hline $\begin{array}{l}\text { Warna permukaan atas } \\
\text { daun }\end{array}$ & hijau & hijau & Hijau & hijau & Ungu & hijau \\
\hline $\begin{array}{l}\text { Warna permukaan bawah } \\
\text { daun }\end{array}$ & hijau & hijau & Hijau & hijau & Ungu & hijau \\
\hline Warna kepala putik & kuning & kuning & Kuning & kuning & Ungu & Kuning \\
\hline Warna mahkota bunga & putih & putih & Putih & putih & Ungu & putih \\
\hline Warna buah muda & kuning & kuning & Kuning & kuning & Ungu & putih kehijauan \\
\hline Warna buah tua & merah & merah & merah tua & merah tua & orange tua & merah tua \\
\hline Bentuk pangkal buah & rompang & tumpul & Tumpul & tumpul & Tumpul & rompang \\
\hline Bentuk ujung buah & tumpul & runcing & Runcing & runcing & Runcing & tumpul \\
\hline Panjang buah & pendek & pendek & Sedang & sedang & Sedang & sedang \\
\hline Bobot buah & sedang & kecil & Sedang & sedang & Kecil & besar \\
\hline Bentuk buah & segitiga & $\begin{array}{l}\text { segitiga } \\
\text { menyempit }\end{array}$ & $\begin{array}{l}\text { segitiga } \\
\text { menyempit }\end{array}$ & $\begin{array}{l}\text { segitiga } \\
\text { menyempit }\end{array}$ & $\begin{array}{l}\text { segitiga } \\
\text { menyempit }\end{array}$ & segitiga \\
\hline Bentuk biji & pipih & $\begin{array}{l}\text { cembung } \\
\text { dibagian tengah }\end{array}$ & Pipih & pipih & Pipih & pipih \\
\hline Bobot biji & sedang & kecil & Berat & berat & Sedang & berat \\
\hline
\end{tabular}

Ayesha merupakan cabai hias ukuran tanaman $d$ warf, buah membulat, jumlah buah lebat, dan banyak warna dalam satu tanaman; (2) Syakira dan Jelita adalah cabai hias ukuran tanaman dwarf, buah memanjang, jumlah buah lebat dan banyak warna dalam satu tanaman; (3) Namira sebagai cabai hias ukuran tanaman dwarf, buah memanjang, ada pemendekan ruas, jumlah buah lebat dan banyak warna dalam satu tanaman; dan (4) Lembayung calon varietas baru cabai hias ukuran tanaman $d$ warf, buah memanjang, jumlah buah lebat dan berwarna ungu dalam satu tanaman.

\section{KESIMPULAN}

Generasi keenam (F6) pada galur Syakira, Jelita, Namira, dan Lembayung hasil persilangan IPB C318 (selfing Explosive Embeer) dengan IPB C092 (selfing dari Seroja) serta galur Ayesha hasil persilangan IPB C318 (selfing Explosive Embeer) dengan IPB C320 (selfing dari Numex Twilight) menunjukan karakter khas padakarakter warna daun ungu pada bagian permukaan atas dan bawah, warna batang ungu, warna buah masak merah, ukuran buah pendek, dan ukuran biji sedang.

Galur Ayesha, Syakira, Jelita, Namira, dan Lembayung memiliki karakter morfologi sesuai denganideotipe yang diharapkan. Ayesha merupakan cabai hias dengan karakter ukuran tanaman dwarf, buah membulat, buah lebat, dan banyak warna dalam satu tanaman. Syakira dan Jelita memiliki ukuran tanaman dwarf, buah memanjang, buah lebat, dan banyak warna dalam satu tanaman. Namira adalah cabai hias dengan ukuran tanaman $d$ warf, buah memanjang, ada pemendekan ruas, buah lebat, dan banyak warna dalam satu tanaman. Lembayung merupakan calon varietas baru cabai hias dengan ukuran tanaman $d$ warf, buah memanjang, buah lebat, dan berwarna ungu dalam satu tanaman. Ayesha, Syakira, Jelita, Namira, dan Lembayung berpotensi dikembangkan sebagai varietas unggul dan diajukan untuk pendaftaran varietas.

\section{UCAPAN TERIMA KASIH}

Terimakasih disampaikan kepada Kementerian Riset dan Teknologi Pendidikan Tinggi yang memfasilitasi pendanaan penelitian SiNas 2015.

\section{DAFTAR PUSTAKA}

Ari E., H. Bedir, S. Yildrim, T. Yildrim. 2016. Androgenic responses of 64 ornamental pepper (Capsicum annuит L.) genotypes to shed-microspore culture in the autumn season. Turk J Biol 40: 706-717. 
Dagnoko S., N. Yaro-Diarisso, PN. Sanogo, O. Adetula, A. Dolo-Nantoumé, K. Gamby-Touré, A. Traoré-Théra, S. Katilé, D. Diallo-B. 2013. Overview of pepper (Capsicum spp.) breeding in West Africa. African Journal of Agricultural Research. 8: 1108-1114.

Eduardo, C. da S. Monteiro, T.N.S. Pereira, K.P. de Campos. 2011. Reproductive characterization of interspecific hybrids among Capsicum species. Crop Breeding and Applied Biotechnology 11: 241-249.

[IPGRI] International Plant Genetic Resources Institute. 1995. Descriptors for Capsicum (Capsicum spp.). International Plant Genetic Resources Institute. Roma. Italia.

[Kementan] Kementrian Pertanian. 2006. Peraturan Menteri Pertanian Nomor : 01/Pert/SR.120/2/2006. Syarat Penamaan dan Tata Cara Pendaftaran Varietas Tanaman. Kementrian Pertanian. Jakarta. Indonesia.

Naktuinbouw. 2010. Calibration Books Capsicum annuum L., Sweet Pepper, Hot Pepper, Paprika, ChiliVersion 1. Naktuinbouw, Variety Testing Department. The Nederlands. 86 pp.

Niu, G., P. Osuna, Y. Sun, D.S. Rodriguez. 2012. Seedling emergence, growth, and mineral nutrition of ornamental chile peppers irrigated with saline water. Hortscience 47:1653-1657.

Occhiuto, P.N., I.E. Peralta, P.D. Asprelli, C.R. Galmarini. 2014. Characterization of Capsicum germplasm collected in Northwestern Argentina based on morphological and quality traits. Agriscientia. 31: 63-73.
[PPVT] Pusat Perlindungan Varietas Tanaman. 2006. Panduan Pengujian Individual Kebaruan, Keunikan, Keseragaman dan Kestabilan Cabai (Capsicum annuum L.). Pusat Perlindungan Varietas Tanaman. Departemen Pertanian Republik Indonesia. Jakarta. Indonesia.

Rego, E.R., M.F. Nascimento, N.F.F. do Nascimento, R.M.C. dos Santos, F.L.G. Fortunato, M.M. do Rego. 2012. Testing methods for producing self-pollinated fruits in ornamental peppers. Horticultura Brasileira 30: 669-672.

Rohlf, F.J. 1998. NTSYS Numerical Taxonomy and Multivariate Analysis System Version 2.0. User guide. New York : Department of Ecology and Evolution State University.

Silva, C.Q., J.M. Jasmim, J.O. Santos, C.S. Bento, C.P. Sudré, R.Rodrigues. 2015. Phenotyping and selecting parents for ornamental purposes in pepper accessions. Horticultura Brasileira 33: 066-073.

Supranto, J. 2004. Analisis Multivariat Arti dan Interpretasi. Rineka Cipta. Jakarta. Indonesia.

Syukur, M., S. Sujiprihati., R. Yunianti. 2015. Teknik Pemuliaan Tanaman, Edisi revisi. Penebar Swadaya. Jakarta. Indonesia.

Zhigila, D.A., A.A. AbdulRahaman, O.S. Kolawole, F.A. Oladele. 2014. Fruit morphology as taxonomic features in five varieties of Capsicum annuum L. Solanaceae. Journal of Botany. 2014: 1-6. 